\title{
CONSTRUCTION AND APPLICATION OF HIGH ENERGY EFFECTIVITY MOBILE MICRO-ECO-HOUSES FOR RECEIVING PROPHYLACTIC PROCEDURES AND SELF-ISOLATION OF CORONAVIRUS COVID-19 AND OTHER DISEASES
}

Edmunds VISOCKIS, Department of Architecture and Building, Faculty of Environmental and Civil Engineering, Latvia University of Life Sciences and Technologies, Jelgava, Latvia, ems@inbox.lv

\begin{abstract}
The scientific article describes an innovative, high energy efficiency construction solution for mobile wooden frame buildings that can be used for various purposes. An interdisciplinary study of the engineering and medical sciences has been described the influence of prophylactic procedures to the human viral infections, such as Coronavirus Covid-19. The micro-eco-houses are intended for receiving various preventive treatment procedures, self-isolation as well as other needs of a wide profile. In climate conditions, where heat energy efficiency requirements are increased, it is provided that will be used a thick layer of thermal insulation, double window and door design solutions, to reduce heat energy losses and cold bridges impact.
\end{abstract}

Keywords: micro-eco-houses; heat energy efficiency; Covid-19; viral preventive procedures, self-isolation.

\section{INTRODUCTION}

The rapid spread of the Coronavirus Covid-19, human infections, serious illnesses and the associated significant deaths are extremely global. In many countries, including Latvia, hospitals and medical staff are overcrowded as almost all of their potential is diverted to the fight against this infectious disease pandemic, by leaving the current treatment of chronic patients in the background. As a result of these conditions, the amount of admitted and severely ill people amount is rising sharply, leading to an increased deaths that are not directly but secondarily linked to the worldwide spread of the Coronavirus Covid-19 pandemic.

The aim of the research is to develop an autonomous mobile low or zero heat energy consumption micro-ecohouses construction concept that can be completed with all the necessary for self-isolation, cold illness symptoms, respiratory virus and other disease prevention procedures, as well as for permanent living and other purposes. Isolating of infected people in such buildings increases the safety conditions for the rest of the human population.

\section{MATERIALS AND METHODS}

The idea of an innovative building construction was developed in cooperation with the teaching staff of Latvia University of Life Sciences and Technologies. For Latvia Republic Patent Office was prepared and submitted a 1 patent application with the title: "Wall and Roof building structure". Application date 21.02.2019, number P-19-10 (Visockis et.al. 2019), and received patent with the title: "Wall and roof cross frame building construction", number of patent: LV 15476 B (Visockis, 2021). Based on the solution described in the patent application, low or zero heat energy consumption micro-eco-house frame structures were developed within the framework of the LLU program "Carrying out fundamental research LLU" scientific internal project G5 "Research and development of innovative low or zero heat energy building construction technologies" and G9 "Development of innovative technologies and their research of concentration and efficient use solar thermal energy in passive and active systems for build up energy efficient buildings" and team involved in the project realisation the innovative mechanical strength properties of wooden frame building structures were studied. The raw data of the building materials used in it were mathematically processed and the strength of frame structures under static and dynamic loads was modelled (Visockis et.al. 2021).

Wood sawn timber with dimensions of $30 \times 100 \times 4800 \mathrm{~mm}$ is used to the construction of low or zero heat energy consumption micro-eco-house frames. To connect wooden structures, different lengths screws with a diameter of 6 mm are used. To the construction bases and floor surfaces are used plywood boards with a thickness 25 and $10 \mathrm{~mm}$. To the construction walls and roof planes are used plywood boards with a thickness $10 \mathrm{~mm}$. To the construction experimental micro-eco-house object are used standard hand tools. The external dimensions of the 1.5-storey experimental object

Copyright (C) 2021 The Authors. Published by Vytautas Magnus University. This is an open-access article distributed under the terms of the Creative Commons Attribution License (CC BY 4.0), which permits unrestricted use, distribution, and reproduction in any medium, provided the original author and source are credited. 
building are $4 \times 5 \mathrm{~m}$, height to the ridge $6.6 \mathrm{~m}$. The dimensions of the interior are $3 \times 4 \mathrm{~m}$, the height at the highest point of the inside edge collision of gable roof structures is 5.68 meters. The room is divided by a 250 mm thick mezzanine floor to create a 1.5 -storey building. The thickness of the thermal insulation filling in the floor is $0.3 \mathrm{~m}$, walls $0.5 \mathrm{~m}$, on the sides of the roof $0.7 \mathrm{~m}$, but in building ridge that receive $1.5 \mathrm{~m}$ thickness. Such dimensions have been applied in accordance by the Latvia climate conditions to receive low or zero heat energy consumptions conditions of buildings and requirements of Latvian construction standards LBN 211-15 "Residential buildings", where it is not necessary to perform project documentations for buildings with a floor area of up to $25 \mathrm{~m}^{2}$, only must to coordinate the building location on the land plot, see Fig. 1 (About the construction...2021; Regulations on the Latvian... 2021).

Due to the compact size, low manufacturing costs and high heat energy efficiency considerations, the micro-ecohouse design is provided without windows, their function is performed by glazed doors. It is planned to place it with glazed front facade to the south side, thus will absorbing and usefully use solar thermal energy. It is envisaged that the side edges of the front facade are also glazed, which makes it possible to absorb the heat energy and light emitted by the morning and evening sun, see Fig.1.

As bulk thermal low-cost insulation materials can be used unprocessed eco-materials of natural origin, such as unwashed sheep's wool, sawdust and shavings-lime mixture, hemp or flax sprouts-lime mixture, worn shredded clothing, etc. By calculating the static and dynamic loads of building structures is taken into account the volume weight of thermal insulation materials.

By using the thermal engineering calculation methods with the planned constructive solution, the energy efficiency indicators of the premises must reach the parameters of low or zero heat energy consumption, which ensures a comfortable internal microclimate in Latvian winter conditions without the need to use basic heating.

To provide fresh outdoor air supply it is planned use pipes of appropriate construction, built into the walls in the required places, to ensuring the required necessary air supply amount $8 \mathrm{~m}^{3} / \mathrm{h}$ for each person. They will be opened and closed with plugs that thickness is equivalent to the thermal insulation layer of the walls. In the closed position plugs will prevent heat losses via fresh outdoor air supply holes. General ventilation for the premises is provided by opening or tilting the doors and windows of glazed facade.

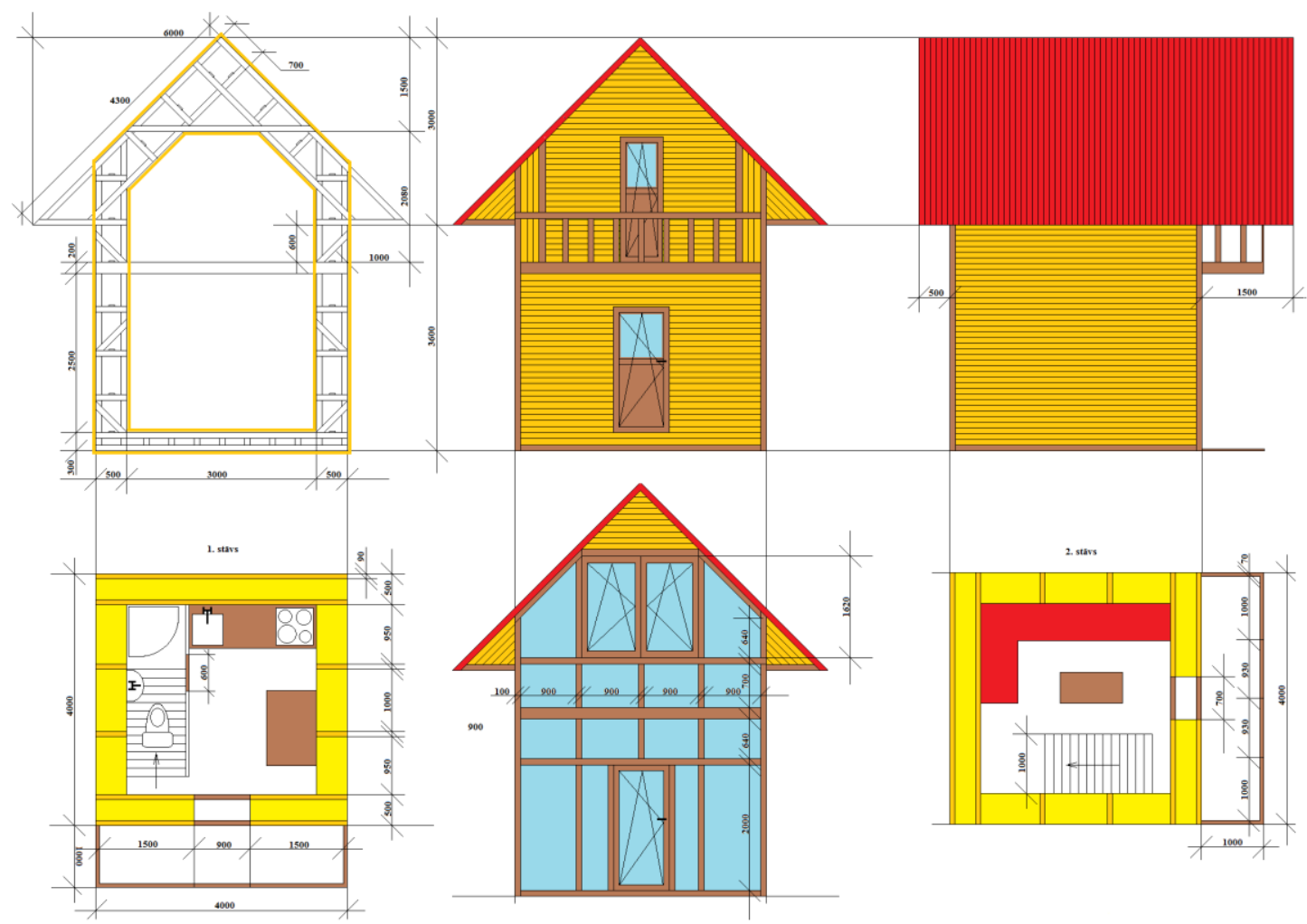

Figure 1. Dimensions, design, layout and equipment of high heat energy efficient mobile micro-eco-houses

To provide infrared ray's treatment procedures in the upper mezzanine floor, it is planned to use electrically operated fireplace, ceramic plates, spirals with a mirror reflector, infrared heating lamps or other devices with an wiring load capacity of 7-10 kW. Their location, installation and control are performed in accordance with the instructions for equipping infrared saunas (Infrared radiators... 2021).

By use the infrared rays sauna, the human body become heated, as a result of which the body temperature rises at 1 to $2{ }^{\circ} \mathrm{C}$, thus warming the tissues to a depth up to $40 \mathrm{~mm}$, simulating the body's reaction to infection, which contributes the death of disease-causing bacteria and viruses (Infrared ray sauna... 2021).

The infrared rays sauna, the advantages and disadvantages of which are known to many peoples of a healthy lifestyle, provides a significant improvement in well-being that occurs after a few procedures. It is recommended to receive every 
second day. The use of infrared ray's sauna provides prevention of some diseases. Therapeutic effect of infrared ray's sauna - when the body temperature rises to $38.5^{\circ} \mathrm{C}$, pathogens die, the body begins to actively fight harmful viruses and infections. The duration of one procedure should not exceed 45 minutes. Regular use the infrared rays sauna promote a quick cure of many pathologies, as well as have a beneficial cosmetic effect. It is known that cancer cells do not tolerate prolonged elevated body temperature. Scientific research around the world has shown that fever, for example in colds, effects of the sudden regression cancers (The elevated body temperature ... 2021). This means that temperature-controlled infrared radiation can be used as a preventive procedure to reduce the risk of cancer, and these types of procedures can be used as an adjunct to treat cancer. Regular visits to the infrared rays sauna give a preventive opportunity to avoid getting illness by viruses.

Harmful effects of too long use of the infrared rays sauna can include overheating of the internal organs, the formation of cataracts, disturbances of the water-salt balance in the body, seizures, heat stroke, and other health problems (Compact infrared sauna... 2021).

At the end of the heating procedure, the room must be ventilated by opening the doors and loggia windows, see Fig.1. If the infrared sauna is used by several people who are not members of the same household, it must be completely disinfected between the periods of receiving their procedures in order to avoid the risk of virus transmission.

\section{RESULTS AND DISCUSSION}

By study this issue experimentally and come to the temporary conclusion that viral infections illness, including Covid-19, can be avoided by almost anyone, if regularly preventive procedures are performed immediately at the occur first symptoms of a cold. The key is to save the body of the virus settling in, avoid of that developing and overcoming of the body's defences. The treatment actually consists of intensive but completely safe preventive procedures in appropriate doses according to the doctor's recommendations. Heating should be performed for an optimal time period, not exceeding the recommendations of doctors. When using an electric infrared source, fireplace or other device, a significant amount of infra-red ray's heat energy is delivered deep into the tissues of the body, as a result it begins to overheat. This environment puts viruses at a disadvantage and they can disappear. To cool down, the body they begins intense sweating, as a result that gets rid also of other harmful substances. By consuming additionally water and food must be restored the optimal balance of salts and other trace elements in the body.

It should also be borne in mind that people who become healthy after infection by Coronavirus Covid-19 are not in same good condition as before the illness, there are often many different types of severe long-term side effects that can even lead to disability. Therefore, it is much better not to get sick than to be successfully cured.

The most ideal form of treatment is prevention. If the incubation period of the virus lasts for more than 2 days, then every second day received prophylactic procedures may significantly reduce the chances of developing the disease, because the virus can be hindered or stopped, what allow the body to overcome the disease without serious consequences. It is very important to create long-lasting, intolerable conditions for the virus in the body, which would make it difficult for it to function and reproduce, as a result of which it would be weakened and destroyed. This would reduce the load on hospitals and the medical staff, as well as reduce financial expenses, patients' planned but not done work activities, etc.

It is known, that the increase in the presence of Corona virus Covid-19 in waste water is detected approximately 5 days before the onset of symptoms in infected people (Multidisciplinary approach... 2021). This information should be used to alert people locally in the media, via mobile phone sms and other means to the onset of symptoms and preventive health promotion recommendations.

If the body's reaction to infection with the virus is rapid and symptoms of the disease appear, then it is recommended to start the procedures mentioned in the article as soon as possible, every minute is important to prevent the symptoms of the disease getting worse. Timely and regular treatment procedures reduce the symptoms of colds and stop the development of viral infections. During the health recovery process, the human immune system acquires information about the structure of the virus construction and function principles, it is possible to develop immune antibodies to further protect the body against these types of infections, similar to the effect of vaccination and to reduce the symptoms of re-infection. Infrared ray's heat, respiratory cleansing vapours, hot silver ion water and the use of healthy, vitamin-rich teas in accordance with the doctor's recommendations in any case have a beneficial effect on the diseased organism, giving the body additional strength to fight the symptoms of the disease. Temperature of potable drinks has a significant effect on the body. For example, if you drink cold milk, water, etc., or hot drinks, the result is instantaneous and diametrically opposite - you will either get even sicker or feel significantly better.

In the current situation caused by the Coronavirus Covid-19 pandemic, it is imperative to seek medical attention for long-term symptoms. In any case, the possibility of being vaccinated with certified vaccines should be used to reduce the risk of viral diseases for yourself and others. At the moment, the situation is unenviable, so is considered that must think about creating a parallel system of preventive medicine, which would make it possible to unburden doctors and hospitals, because at present it is almost impossible to treat people stationary by other non-acute diseases.

It is very important to ensure in buildings a constant supply of clean, fresh outdoor air and a relatively high indoor air temperature, preferably not lower than $+30{ }^{\circ} \mathrm{C}$. By breathing clear, fresh and warm air with optimal oxygen concentration, when that entering in the lungs it does not cool the body so intensively and allows provide a warmer environment than everyday indoor microclimate conditions, thus ensure more comfortable conditions for a sick persons, but a more unfavourable environment for virus infection. That enables the body to overcome a critical point and concentrate the people body immune system defence mechanisms power potential to the fight against the disease caused by the virus. As a result of infrared ray's sauna procedures and for therapeutic purposes in accordance with the 
recommendations of doctors, it is desirable to take a variety of health-promoting teas and infusions to compensate the losses of fluid and salt in the body, to ensuring their optimal balance.

As it is known, water stored in heavy metal - silver utensils for a long time has antibacterial properties. The device Aqua Vita Silver + allows to prepare silver water (containing silver ions) in a high concentration in a relatively short time - the maximal is prepared in 200 minutes (Water ionizer... 2021). An innovative approach was tested in the pilot studies of this publication - boiling the silver water prepared in this way and drink it hot, thus obtaining an additional hot tea effect, which give a double positive effect against the symptoms of viral illness. Even this device makes it possible to prepare ionized alkaline water, which has a beneficial effect on the body, neutralizing the acidic environment accumulated in it. It works as a preventative measure to reduce the risks of many diseases.

In scientific research is known that people with an acidified body environment have an increased risk of developing cancer. Therefore, there is reason to consider that the consumption of alkaline water for prophylactic purposes reduces this kind of risk and can be used as an adjunct for cancer treatment. Alkaline water helps prevent many chronic diseases, including oncological pathologies. Alkaline water prevents the accumulation of free radicals in the body, thus relieving the body of toxins. Prophylactic use of alkaline water normalizes blood $\mathrm{pH}$ and normalizes circulatory processes. Water with a high alkaline content moisturizes the body's cells, preventing premature aging processes (Alkaline water kills cancer... 2021). Inexpensive and discounted low-quality food sold in stores with near-expiration date or stored in inappropriate storage conditions is often already spoiled, so it contains harmful substances and toxins, and therefore is not recommended for eating. Prolonged or delay consumption of low-quality food increases the risk of cancer, so it is important to regularly use various preventive activities to neutralize the acidic and toxic environment in the body.

Acid water prepared in that device is also used for various preventive and disinfection purposes. Use of water prepared that device should be done according to the doctor's instructions (Recomendations for the use... 2021).

The micro-eco-houses can be equipped with all equipment what necessary to ensure a person's permanent living. There it is possible to boil a pot with potatoes. When they boiled, the water must drain, and so that it does not burn the people body airways, must breathe hot vapours until they cool down. It is a traditional folk method for the prophylactic treatment of respiratory infections diseases in the early stages, that way effectively cleansing of sputum all components of the body breathing system.

In the framework of experimental studies, it was found that the procedures described in the publication have a positive effect to health and immunity strengthens, therefore it is recommended to use them at home for preventive purposes. When used at doses recommended by doctors, they do not cause any harmful side effects and allow start treatment immediately, without delay and avoid the disease to continue progress.

The use of such prophylactic procedures can be an alternative temporary solution to the current situation in the world, where medicine drugs for the treatment of Coronavirus Covid-19 are not currently available and the vaccine for most peoples is lacking many months. Timely, immediately initiation of treatment allows easier recovery and gets immune protection against recurrence of similar types of viruses and other illnesses.

\section{CONCLUSIONS}

1. High energy efficiency mobile micro-eco-houses structural design, equipment and facilities may be used for prophylactic procedures of various respiratory viral infections including coronavirus Covid-19, oncological dieselises, self-isolation, as well as other periodic and permanent residence needs.

2. The use of mobile high-energy micro-eco-houses in accordance with their intended use by accommodating there easy ill patients can significantly decrease loads to medical institutions and that way give possibility for acute and severely ill patients providing a high level professional medical care.

3. The use of hot silver ionic antibacterial water for prophylactic respiratory treatment significantly increases its effectiveness.

\section{Acknowlegments}

1. Funding of the LLU program "Carrying out fundamental research LLU", scientific project G5 "Research and development of innovative low or zero heat energy building construction technologies" and team involved in the project realisation.

2. Funding of the LLU program "Carrying out fundamental research LLU", scientific project G9 "Development of innovative technologies and their research of concentration and efficient use solar thermal energy in passive and active systems for build up energy efficient buildings" and team involved in the project realisation.

3. GmBH "Jelgavas nekustama ipasuma parvalde" for support in the implementation of research.

4. Association "ECOtechnologies" for support in the implementation of research.

\section{REFERENCES}

1. Visockis E., Skujans J., Gusta S., Pleiksnis S., Selegovskis R. 2019. Patent application: "Wall and Roof building structure". Application date 21.02.2019, number P-19-10. Applicant: Latvia University of Life Sciences and Technologies

2. Visockis E. 2020. Received patent: “Wall and roof cross frame building construction”. Application number P-19-30, date 18.06.2019. Number of patent: LV 15476 B. Date of application publication: 20.01.2020., date of patent publication: 20.04.2021.

3. Visockis E., Vītoliņ̌š O., Gusta S. 2021. Innovative frame wood constructions application concept development for high energy efficiency buildings. Research for Rural Development LLU, pp. 403-408. 
4. About the construction of small houses (in Latvian: Par mazēku būvniecību). Available: https://geometrs.lv/2019/05/14/parmazeku-buvniecibu/ (Accessed: 16.02.2021).

5. Regulations on the Latvian construction standard LBN 211-15 "Residential buildings" (in Latvian: Noteikumi par Latvijas būvnormatīvu LBN 211-15 "Dzīvojamās ēkas") Available: https://likumi.lv/ta/id/275016-noteikumi-par-latvijas-buvnormativulbn-211-15-dzivojamas-ekas- (Accessed: 12.03.2021).

6. Infrared radiators for saunas: How to choose equipment? (in Latvian: Infrasarkanie radiatori saunām: Kā izvēlēties aprīkojumu?) Available: https://lav.thehouseofchronic.com/3949012-infrared-radiators-for-saunas-how-to-choose-equipment (Accessed: 16.02.2021).

7. Infrared ray sauna (in Latvian: Infrasarkano staru pirts) Available: https://www.stradini.lv/lv/content/infrasarkano-staru-pirts (Accessed: 15.02.2021).

8. Compact infrared sauna: benefits and harms, tips and tricks. What is an infrared sauna? Benefits and harm to the body (in Russian: Компактная инфракрасная сауна: польза и вред, советы и рекомендации. Что такое инфракрасная сауна? Польза и вред для организма) Available: https:/gameasphalt.ru/kompaktnaya-infrakrasnaya-sauna-polza-i-vred-sovety-i/ (Accessed: 15.02.2021).

9. The elevated body temperature can save from the cancer (in Latvian: Paaugstināta temperatūra var paglābt no vēža) [Online] [Accessed: 15.08.2021]. Available https://jauns.lv/raksts/par-veselibu/107534-ko-arsti-tev-nestasta-paaugstinata-temperaturavar-paglabt-no-veza

10. Multidisciplinary approach to monitoring, control and control of COVID19 and other future epidemics in Latvia (in Latvian: Multidisciplināra pieeja COVID19 un citu nākotnes epidēmiju monitorēšanai, kontrolei un ierobežošanai Latvijā) Available: https://www.lu.lv/covid19-vpp/aktualitates/aktualitates/ (Accessed: 15.02.2021).

11. Water ionizer Aquavita Silver (in Latvian: Ūdens jonizators Aquavita Silver) Available: https://akvavita.lv/katalogs/udensjonizatori/aquavita-silver/ (Accessed: 15.02.2021).

12. Alkaline water kills cancer and removes toxins (in Latvian: Sārmains ūdens nogalina vēzi un izvada toksīnus) [Online] [Accessed: 15.02.2021]. Available: https://abiem.lv/sarmains-udens-nogalina-vezi-izvada-toksinus-un-dava-ilgu-dzivi-bet-ka-gan-taduuztaisit/43636

13. Reccomendations for the use of ionized water (in Latvian: Jonizētā ūdens izmantošanas rekomendācijas) Available: https://akvalife.club/lv/rekomendacijas-jonizeta-udens-pielietosana-doc-pjatras-sibilskis.html (Accessed: 15.02.2021). 